\title{
Distribution and Some Properties of Tryptophan Hydroxylase from Liver in Several Fishes
}

\author{
Takeshi Nagai, ${ }^{* 1,2}$ Moritsugu Hamada, ${ }^{* 1}$ Norihisa Kai, ${ }^{* 1}$ Yasuhiro Tanoue, ${ }^{* 1}$ and \\ Fumio Nagayama*2†
}

*1Department of Food Science and Technology, National Fisheries University, Nagata-honmachi, Shimonoseki, Yamaguchi 759-65, Japan

${ }^{* 2}$ Department of Food Science and Technology, Tokyo University of Fisheries, Konan, Minato, Tokyo 108, Japan

(Received May, 9, 1994)

Key words: tryptophan hydroxylase, fish, liver, $K_{\mathrm{m}}$ value

Tryptophan hydroxylase [L-Tryptophan, tetrahydropteridine: oxygen oxidoreductase (5-hydroxylating) EC 1.14.16.4] catalyzes the conversion of tryptophan to 5hydroxytryptophan. This enzyme is of great interest because it is one of the three known pterin-requiring aromatic amino acid hydroxylases and catalyzes the rate-limiting step in the biosynthesis of serotonin in the brain and other peripheral tissues. ${ }^{1-3)}$ It was first discovered in mammalia, ${ }^{4)}$ and purified from rat brain stem and mouse mastocytoma. ${ }^{5,6}$

On the other hand, this enzyme in fish has not been studied in detail yet, 7 and its distribution and characterization have not been clarified. As a part of studies on serotonin biosynthesis in fish, tryptophan hydroxylase activity in the liver of several fishes was surveyed in this paper.

Fish samples were purchased from the Tokyo Central Wholesale Market. Their livers were excised then stored at $-80^{\circ} \mathrm{C}$ until use. Liver samples were homogenized with 3 volumes of $50 \mathrm{mM}$ Tris-acetate buffer $(\mathrm{pH} \mathrm{7.6)}$ containing $2 \mathrm{mM}$ phenylmethylsulfonyl fluoride (PMSF) and $4 \mathrm{mM}$ 2-mercaptoethanol (2-ME) in a Potter-Elvehjem homogenizer with a motor-driven teflon pestle.

The homogenate was centrifuged at $100,000 \times \mathrm{g}$ for 30 min. The supernatant was filtered through glass wool, and the filtrates were used as a crude enzyme solution. The reaction mixture contained $0.05 \mathrm{~m} l$ of $1 \mathrm{mM}$ ferrus ammonium sulfate, $0.57 \mathrm{ml}$ of $1 \mathrm{M}$ HEPFS buffer $(\mathrm{pH} \mathrm{7.6)}, 0.025 \mathrm{ml}$ of $20 \mathrm{mg} / \mathrm{ml}$ catalase, $0.05 \mathrm{ml}$ of $5 \mathrm{mM} \mathrm{D}$, L-6-methyl-5, 6 , 7, 8-tetrahydropterine in $10 \mathrm{mM} \mathrm{HCl}, 0.05 \mathrm{ml}$ of $10 \mathrm{mM} \mathrm{L}-$ tryptophan, $0.025 \mathrm{~m} l$ of $0.2 \mathrm{M} 2-\mathrm{ME}, 0.38 \mathrm{ml}$ of $\mathrm{H}_{2} \mathrm{O}$, and $0.1 \mathrm{~m} l$ of the enzyme preparation. The reaction was started by the addition of D, L-6-methyl-5, 6, 7, 8-tetrahydropterine. The reaction mixture was incubated at $35^{\circ} \mathrm{C}$ for 30 min with mild shaking. The reaction was stopped by the addition of $0.125 \mathrm{~m} l$ of $40 \%$ perchloric acid. After the precipitated protein was removed by centrifugation, a 1.0 $\mathrm{m} l$ aliquot of the supernatant was withdrawn and mixed with $1.5 \mathrm{ml}$ of $5 \mathrm{~N} \mathrm{HCl}^{8}{ }^{8}$ The fiuorescence of the solution was measured at an excitation wavelength of $295 \mathrm{~nm}$ and emission of $530 \mathrm{~nm}$ by the method of Friedman et al. ${ }^{2)}$ The enzyme activity was expressed as the activity which produces $1 \mathrm{nmol}$ of 5-hydroxytryptophan per min per $g$ of tissue.

Table 1 shows tryptophan hydroxylase activity in the livers of 16 fish species. Skipjack, croaker, and sweetfish showed a considerably higher activity compared with grass carp, eel, and red sea bream. On the other hand, no activity was found in saury, horse mackerel, sardine, and Pacific cod. For comparison, some invertebrates such as arrow squid, swimming crab, and scallop were examined, but little or no activity was detected.

Optimum pH, optimum temperature, and $K_{\mathrm{m}}$ value are summarized in Table 1. The optimum $\mathrm{pH}$ for the enzyme reaction was found to be $7.0-8.2$ which is similar to that for rat stem and mouse mastocytoma enzymes. ${ }^{5,6)}$ Serrano and Nagayama ${ }^{7}$ reported that optimum $\mathrm{pHs}$ for the enzymes from tilapia, grass carp, common carp, and rainbow trout were $8.5,7.0,9.0$, and 8.0 , respectively.

The optimum temperature rauge was $30-37^{\circ} \mathrm{C}$. The $K_{\mathrm{m}}$ values for $\mathrm{L}$-tryptophan were $0.0042-0.92 \mathrm{~mm}$; sweetfish

Table 1. Characterization of tryptophan hydroxylase in fish liver

\begin{tabular}{lcccc}
\hline Species & Activity & $\begin{array}{c}\text { Optimum } \\
\mathrm{pH}\end{array}$ & $\begin{array}{c}\text { Optimum } \\
\text { temp } \\
\left({ }^{\circ} \mathrm{C}\right)\end{array}$ & $\begin{array}{c}K_{\mathrm{m}} \\
(\mathrm{mM})\end{array}$ \\
\hline Skipjack & 134 & 8.2 & 35 & 0.27 \\
Croaker & 129 & 7.4 & 37 & 0.39 \\
Sweetfish & 92 & 8.2 & 35 & 0.92 \\
Japanese sea-bass & 77 & 7.8 & 37 & 0.012 \\
Rainbow trout & 65 & 7.4 & 37 & 0.46 \\
Autumn albacore & 62 & 7.6 & 35 & 0.50 \\
Chub mackerel & 56 & 7.6 & 35 & 0.013 \\
Yellowtail & 51 & 7.4 & 37 & 0.34 \\
Eel & 22 & 7.6 & 30 & 0.21 \\
Red sea bream & 18 & 7.6 & 30 & - \\
Grass carp & 10 & 7.0 & 35 & 0.16 \\
Three-line grunt & 3 & 7.4 & 37 & 0.0042 \\
Horse mackerel & ND & - & - & - \\
Pacific cod & ND & - & - & - \\
Sardine & ND & - & - & - \\
Saury & ND & - & - & -
\end{tabular}

* n mol product / min per $g$ tissue at $\mathrm{pH} 7.6$ and $35^{\circ} \mathrm{C}$.

ND, not detected; - not determined. 
showed the highest value and three-line grunt showed the lowest value. The $K_{\mathrm{m}}$ values of Japanese sea-bass and chub mackerel enzymes were comparable to those obtained for rat brain and mouse mastocytoma. ${ }^{5,6)}$ In grass carp, the $K_{\mathrm{m}}$ value of the enzyme was reported to be $1.27 \mathrm{mM}^{7}$, which is for higher than the value of $(0.16 \mathrm{~mm})$ in Table 1 .

From the present results, the activity of tryptophan hydroxylase in fish liver did not seem to be species specific, and while it was detected in many species, it was not detected in saury, horse mackerel, sardine, and Pacific cod. The $K_{\mathrm{m}}$ values varied greathy among these fishes, but the enzyme from fish liver clearly had a considerably lower affinity for the substrate compared with that from mammals.

This research was supported in part by a Grant-in-Aid for Scientific Research from the Ministry of Education,
Science and Culture.

\section{References}

1) A. Ichiyama, S. Nakamura, Y. Nishizuka, and O. Hayaishi: J. Biol, Chem., 245 1699-1709 (1970).

2) P. A. Friedman, A. H. Kappelman, and S. Kaufman: J. Biol. Chem., 247, 4165-4173 (1972).

3) F. Jequier, W. Lovenberg, and A. Sjoerdsma: Mol. Pharmacol., 3, 274-278 (1967).

4) W. Lovenberg, E. Jequier, and A. Sjoerdsma: Science, 155, 217-219 (1967).

5) H. Nakata and H. Fujisawa: Eur. J. Biochem., 122, 41-47 (1982).

6) H. Nakata and H. Fujisawa: Eur. J. Biochem., 124, 595-601 (1982),

7) A. E. Serrano and F. Nagayama: Comp. Biochem. Physiol., 98B, 275-280 (1991).

8) H. Fujisawa and H. Nakata: "Methods in Enzymology" Vol. 142, 1987, pp. 83-87. 